\title{
Editorial I \\ Reproductive health issues, infections and non-communicable diseases
}

\author{
James K Tumwine
}

Editor in Chief, African Health Sciences.

DOI: https://dx.doi.org/10.4314/ahs.v20i1.1

Cite as: Tumwine JK. Reproductive health issues, infections and non-communicable diseases. Afri Health Sci. 2020;20(1):I-IV. bttps:/ / dx.doi.org/10.4314/abs.v20i1.1

Welcome to this bumper March 2020 issue of African Health Sciences. The first five papers in this issue are on sexuality in men and adolescents. Hence Lampiao and Chisaka have written an interesting research article on the incidence and impact of hyperviscosity on sperm parameters of Malawian men seeking assisted reproduction'1. A similar paper from Tanzania reports on 'bacteriospermia' and other factors associated with male infertility ${ }^{2}$. The next three articles are on sexual behaviour and practice. They include: 'use of sachet alcohol and sexual behaviour among adolescents in Nigeria $^{3}$; sexual knowledge and practice of adolescent learners in rural South Africa ${ }^{4}$; and sexual behaviours and risk perception of STIs among polytechnic students' in Nigeria $^{5}$.

The next group of papers are on, yes you have guessed right, infectious diseases. They cover uptake of human papilloma virus vaccines among female secondary school students; ${ }^{6}$ Candida spp. and age-related disparities amongst women presenting with vaginitis; ${ }^{7}$ and toxoplasmosis in pregnant women ${ }^{8}$. Continuing with the pregnancy theme, we have a paper on the use of alternative medicines during pregnancy in Zimbabwe ${ }^{9}$; and outcome of gestational trophoblastic disease in Egypt ${ }^{10}$. The infectious disease theme continues with work on HIV-related knowledge level among Indonesian wom$\mathrm{en}^{11}$ and a systematic review of $\mathrm{ARVs}^{12}$. There are more papers: chronic HIV infection and health related quality of life in resource poor settings ${ }^{13}$; cryptococcosis among HIV patients in sub-Saharan Africa ${ }^{14}$; malnutrition amongst HIV adult patients ${ }^{15}$; viral suppression and low attrition in healthy HIV-infected patients initiated on ART with CD4 above 500 cells $/ \mu \mathrm{L}^{16}$; acceptance and utilization of HIV testing among the youth ${ }^{17}$; rabies in Kwazulu-Natal ${ }^{18}$; and central line-related bloodstream infections ${ }^{19}$. There are papers on Stenotrophomonas species ${ }^{20}$; risk factors for trachoma in Burundi ${ }^{21}$; plasmid-mediated resistance genes and multidrug-resistant uropathogens ${ }^{22}$; prevalence of plasmodium, leptospira and rickettsia ${ }^{23}$; seroepidemiology of human fascioliasis ${ }^{24}$; Parvovirus B19 DNA detection in HIV anemic patients ${ }^{25}$; safety of vaccines used in rou- tine immunization in Africa ${ }^{26}$ and distribution of genes among uropathogenic Escherichia coli and antimicrobial resistance ${ }^{27}$.

The next group of papers is in the NCDs realm: obesity $^{28,29,30}$, diabetes ${ }^{31,32,33,34}$, acute kidney injury ${ }^{35}$ plasma homocysteine and hypertension ${ }^{36}$, coronary care $^{37}$ and cancer ${ }^{38,39}$. Then we have papers on smoking and lung function $^{40}$, epilepsy ${ }^{41}$, and gall stones ${ }^{42}$. One major observation made in patients with Covid_19 is hypercoagulability. We have a related article on hypercoagulability in sickle cell disease ${ }^{43}$.

Other NCD papers are on hyperbilirubinemia ${ }^{44}$, zinc deficiency in children, ${ }^{45}$ effect of pumpkin seed oil on oxidative stress, ${ }^{46}$ upper GI haemorrhage, ${ }^{47}$ vitamin D deficiency $^{48}$ and cystic fibrosis in Tunisia ${ }^{49}$. We have articles on risks associated with health care waste management ${ }^{50}$; anti-proliferative effects of Amarillydacea $e^{51}$; periodontal and dental conditions in a volcanic region with highly fluoridated community drinking water ${ }^{52}$; effects of head-of-bed elevation on respiratory pattern ${ }^{53}$; kangaroo mother care outcomes ${ }^{54}$; and ultrasound and carotid stenosis ${ }^{55}$. Others are on unorthodox ophthalmic preparations in Ghana ${ }^{56}$, feeding and swallowing difficulties of children with Autism Spectrum Disorders ${ }^{57}$; visual impairment ${ }^{58}$; and two letters to the editor ${ }^{59,60}$. Quite a rich menu. Happy reading!

\section{References}

1. Lampiao F, Chisaka J. Incidence and impact of hyperviscosity on sperm parameters of Malawian men seeking assisted reproduction. Afri Health Sci. 2020;20(1):13. https://dx.doi.org/10.4314/ahs.v20i1.3

2. Silago V, Mukama Y, Haule AL, Chacha F, Igenge J, Mushi MF, et al. Bacteriospermia, extended spectrum beta lactamase producing Gram-negative bacteria and other factors associated with male infertility in Mwanza, Tanzania: a need of diagnostic bacteriology for management of male infertility. Afri Health Sci. 2020;20(1):413. https://dx.doi.org/10.4314/ahs.v20i1.4

3. Oluwaseunfunmi A, Ademola A. Use of sachet alcohol and sexual behaviour among adolescents in Ibadan,

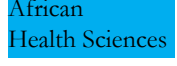

(C) 2020 Tumwine JK. Licensee African Health Sciences. This is an Open Access article distributed under the terms of the Creative commons Attribution License (https://creativecommons.org/licenses/BY/4.0), which permits unrestricted use, distribution, and reproduction in any medium, provided the original work is properly cited.

African Health Sciences Vol 20 Issue 1, March, 2020 
Nigeria. Afri Health Sci. 2020;20(1):14-27. https://dx. doi.org/10.4314/ahs.v20i1.5

4. Mostert K, Sethole KM, Khumisi O, Peu D, Thambura J, Ngunyulu RN, et al. Sexual knowledge and practice of adolescent learners in a rural South African school. Afri Health Sci. 2020;20(1):28-3. https://dx.doi. org/10.4314/ahs.v20i1.6

5. Oharume IM. Knowledge, sexual behaviours and risk perception of sexually transmitted infections among students of the polytechnic, Ibadan, Oyo state. Afri Health Sci. 2020;20(1):39-44. https://dx.doi.org/10.4314/ahs. v20i1.7

6. Ezeanochie M, Olasimbo P. Awareness and uptake of human papilloma virus vaccines among female secondary school students in Benin City, Nigeria. Afri Health Sci. 2020;20(1):45-50. https://dx.doi.org/10.4314/ahs. v20i1.8

7. Mbakwem-Aniebo C, Osadebe AU, Athanasonny E, Okonko IO. Prevalence of Candida spp. and age-related disparities amongst women presenting with vaginitis at the Obstetrics and Gynaecology (O\&G) Clinic in a Tertiary hospital in Port Harcourt, Nigeria. Afri Health Sci. 2020;20(1):51-8. https://dx.doi.org/10.4314/ahs. v20i1.9

8. Hoummadi L, Berrouch S, Amraouza Y, Adel A, Mriouch M, Soraa N, et al. Seroprevalence of toxoplasmosis in pregnant women of the Marrakech-Safi region, Morocco. Afri Health Sci. 2020;20(1):59-63. https://dx.doi.org/10.4314/ahs.v20i1.10

9. Dimene L, Fadzai M, Chifamba J, Nyakatawa G, Mahachi $\mathrm{C}$, Marume A, et al. A cross-sectional study to determine the use of alternative medicines during pregnancy in the district hospitals in Manicaland, Zimbabwe. Afri Health Sci. 2020;20(1):64-72. https://dx.doi. org/10.4314/ahs.v20i1.11

10. Zakaria A, Hemida R, Elrefaie W, Refaie E. Incidence and outcome of gestational trophoblastic disease in lower Egypt. Afri Health Sci. 2020;20(1):73-82. https://dx.doi.org/10.4314/ahs.v20i1.12

11. Efendi F, Pratama ER, Hadisuyatmana S, Indarwati R, Lindayani L, Bushy A. HIV-related knowledge level among Indonesian women between 15 years and 49 years of age. Afri Health Sci. 2020;20(1):83-90. https:// dx.doi.org/10.4314/ahs.v20i1.13

12. Tigabu BM, Agide FD, Mohraz M, Nikfar S. Atazanavir / ritonavir versus Lopinavir / ritonavir-based combined antiretroviral therapy (cART) for HIV-1 infection: a systematic review and meta-analysis. Afri Health Sci. 2020;20(1):91-101. https://dx.doi.org/10.4314/ ahs.v20i1.14

13. Onyekonwu CL, Onyeka TC, Brenda NC, Ijoma UN, Unaogu NN, Onwuekwe IO, et al. Chronic HIV infection and health related quality of life in resource poor settings-an assessment from South East Nigeria. Afri Health Sci. 2020;20(1):102-13. https://dx.doi. org/10.4314/ahs.v20i1.15

14. Alemayehu T, Ayalew S, Buzayehu T, Daka D. Magnitude of Cryptococcosis among HIV patients in sub-Saharan Africa countries: a systematic review and meta-analysis. Afri Health Sci. 2020;20(1):114-21. https://dx.doi.org/10.4314/ahs.v20i1.16

15. Odwee A, Kasozi KI, Acup CA, Kyamanywa P, Ssebuufu R, Obura R, et al. Malnutrition amongst HIV adult patients in selected hospitals of Bushenyi district in southwestern Uganda. Afri Health Sci. 2020;20(1):12231. https://dx.doi.org/10.4314/ahs.v20i1.17

16. Byonanebye DM, Semitala FC, Katende J, Bakenga A, Arinaitwe I, Kyambadde P, et al. High viral suppression and low attrition in healthy HIV-infected patients initiated on ART with CD 4 above 500 cells $/ \mu \mathrm{L}$ in a program setting in Uganda. Afri Health Sci. 2020;20(1):13241. https://dx.doi.org/10.4314/ahs.v20i1.18

17. Asare BYA, Yeboaa HY, Dwumfour-Asare B. Acceptance and utilization of HIV testing among the youth: a cross-sectional study in Techiman, Ghana. Afri Health Sci. 2020;20(1):142-9. https://dx.doi. org/10.4314/ahs.v20i1.19

18. Hadebe JM, Sibiya MN. Experiences of people affected by rabies in Ethekwini district in the province of Kwazulu-Natal, South Africa. Afri Health Sci. 2020;20(1):150-7. https://dx.doi.org/10.4314/ahs. v20i1.20

19. Nahla KS, Manal IS, Gehan MA. Central line-related bloodstream infections and microbiological study in an Egyptian Ministry of Health Hospital. Afri Health Sci. 2020;20(1):158-67. https://dx.doi.org/10.4314/ ahs.v20i1.21

20. Elufisan TO, Rodriguez-Luna IC, Oyedara OO, Sanchez-Varela A, Virgilio B-G, Oluyide BO, et al. Antimicrobial susceptibility pattern of Stenotrophomonas species isolated from Mexico. Afri Health Sci. 2020;20(1):168-81.https://dx.doi.org/10.4314/ahs. v20i1.22

21. Ndisabiye D, Gahungu A, Kayugi D, Waters EK. Association of environmental risk factors and trachoma in Gashoho Health District, Burundi. Afri Health Sci. 2020;20(1):182-9. https://dx.doi.org/10.4314/ahs. v20i1.23

22. Elshamy AA, Aboshanab KM, Yassien MA, Hassouna NA. Prevalence of plasmid-mediated resistance genes among multidrug-resistant uropathogens in Egypt Afri Health Sci. 2020;20(1):190-8. https:/ /dx.doi. org/10.4314/ahs.v20i1.24

23. Chilongola JO, Sabuni EJ, Kapyolo EP. Prevalence 
of plasmodium, leptospira and rickettsia species in Northern Tanzanian: a community based survey. Afri Health Sci. 2020;20(1):199-207. https://dx.doi.org/10.4314/ ahs.v20i1.25

24. Afshan K, Kabeer S, Firasat S, Jahan S, Qayyum M. Seroepidemiology of human fascioliasis and its relationship with anti-Fasciola IgG and liver enzymes as biomarkers of pathogenicity. Afri Health Sci. 2020;20(1):208-18. https://dx.doi.org/10.4314/ahs.v20i1.26

25. Ashaka OS, Salu OB, James AB, Oyefolu AOB, Anjorin AA, Oke BO, et al. Parvovirus B19 DNA detection in treatment-naïve HIV anemic patients in Lagos, Nigeria: a case control study. Afri Health Sci. 2020;20(1):21926. https://dx.doi.org/10.4314/ahs.v20i1.27

26. Yamoah P, Bangalee V, Oosthuizen F. A review of the safety of vaccines used in routine immunization in Africa. Afri Health Sci. 2020;20(1):227-37. https://dx. doi.org/10.4314/ahs.v20i1.28

27. Kadry AA, Al-Kashef NM, El-Ganiny AM. Distribution of genes encoding adhesins and biofilm formation capacity among Uropathogenic Escherichia coli isolates in relation to the antimicrobial resistance. Afri Health Sci. 2020;20(1):238-47. https://dx.doi. org/10.4314/ahs.v20i1.29

28. Mařincová L, Šafaříková S, Cahlíková R. Analysis of main risk factors contributing to obesity in the region of East Africa: meta-analysis. Afri Health Sci. 2020;20(1):248-56.https://dx.doi.org/10.4314/ahs. v20i1.30

29. Hadi S, Momenan M, Cheraghpour K, Hafizi N, Pourjavidi N, Malekahmadi M, et al. Abdominal volume index: a predictive measure in relationship between depression/anxiety and obesity Afri Health Sci. 2020;20(1):257-65.https://dx.doi.org/10.4314/ahs. v20i1.31

30. Elamin MA, Youseif SM, Mohammed HA. Ghrelin, resistin and insulin in obese diabetic women in Wad-Madani, Sudan Afri Health Sci. 2020;20(1):266-76. https://dx.doi.org/10.4314/ahs.v20i1.32

31. Demir AK, Şahin S, Kaya SU, Bütün İ, Çıtıl R, Önder Y; et al. Prevalence of insulin resistance and identifying HOMA1-IR and HOMA2-IR indexes in the Middle Black Sea region of Turkey. Afri Health Sci. 2020;20(1):277-86.https://dx.doi.org/10.4314/ahs. v20i1.33

32. Hasanato RMW. Trace elements in type 2 diabetes mellitus and their association with glycemic control. Afri Health Sci. 2020;20(1):287-93. https://dx.doi. org/10.4314/ahs.v20i1.34

33. Enikuomehin A, Kolawole BA, Soyoye OD, Adebayo JO, Ikem RT. Influence of gender on the distribution of type 2 diabetic complications at the obafemi awolowo teaching hospital, Ile-Ife, Nigeria. Afri Health Sci. 2020;20(1):294-307. https://dx.doi.org/10.4314/ ahs.v20i1.35

34. Vijayaraghavan B, Padmanabhan G, Ramanathan K. Determination of serum glycated albumin and high sensitivity $\mathrm{C}$ - reactive protein in the insight of cardiovascular complications in diabetic chronic kidney disease patients. Afri Health Sci. 2020;20(1):308-13. https://dx.doi.org/10.4314/ahs.v20i1.36

35. Anigilaje EA, Fashie AP, Odeyemi B, Yakubu A. Acute peritoneal dialysis in children with acute kidney injury at the University of Abuja Teaching Hospital, Abuja, Nigeria: a report of 12 months experience in a developing country. Afri Health Sci. 2020;20(1):314-23. https://dx.doi.org/10.4314/ahs.v20i1.37

36. Onyemelukwe OU, Maiha BB. Relationship between plasma homocysteine and blood pressure in hypertensive Northern-Nigerians. Afri Health Sci. 2020;20(1):32437. https://dx.doi.org/10.4314/ahs.v20i1.38

37. Stassen W, Kurland L, Wallis L, Castren M, Vincent-Lambert C. Barriers and facilitators to implementing coronary care networks in South Africa: a qualitative study. Afri Health Sci. 2020;20(1):338-50. https:// dx.doi.org/10.4314/ahs.v20i1.39

38. Wang Y, Hu P. Association between the Interleukin-10 -1082 G/A polymorphism and risk of hepatocellular carcinoma. Afri Health Sci. 2020;20(1):351-8. https://dx.doi.org/10.4314/ahs.v20i1.40

39. Moodley Y, Madiba T. Out-patient visits for gastrointestinal cancer at a quaternary South African hospital-trends and geospatial distribution. Afri Health Sci. 2020;20(1):359-67.https://dx.doi.org/10.4314/ahs. v20i1.41

40. Elshazly FA, Abdelbasset WK, Elnaggar RK, Tantawy SA. Effects of second-hand smoking on lung functions in athlete and non-athlete school-aged children observational study. Afri Health Sci. 2020;20(1):368-75. https://dx.doi.org/10.4314/ahs.v20i1.42

41. Kirabira J, Forry BJ, Fallen R, Sserwanga B, Rukundo GZ. Perceived stigma and school attendance among children and adolescents with epilepsy in South Western Uganda. Afri Health Sci. 2020;20(1):376-82. https:/ / dx.doi.org/10.4314/ahs.v20i1.43

42. Nimanya S, Ocen W, Makobore P, Bua E, Ssekitooleko B, Oyania F. Prevalence and risk factors of gallstone disease in patients undergoing ultrasonography at $\mathrm{Mu}-$ lago hospital, Uganda. Afri Health Sci. 2020;20(1):38391. https://dx.doi.org/10.4314/ahs.v20i1.44

43. Mohamed EA, Elgari MM, Babker AM, Waggiallah HA. Comparative study of hypercoagulability change in steady state and during vaso-occlusive crisis among Sudanese patients living with sickle cell disease. Afri Health 
Sci. 2020;20(1):392-6. https://dx.doi.org/10.4314/ahs. v20i1.45

44. Nyangabyaki-Twesigye C, Mworozi E, Namisi C, Nakibuuka V, Ssebunya R, Mukose DA. Prevalence, factors associated and treatment outcome of hyperbilirubinaemia in neonates admitted to St Francis hospital, Nsambya, Uganda: a descriptive study. Afri Health Sci. 2020;20(1):397-405.https://dx.doi.org/10.4314/ahs. v20i1.46

45. Abolurin OO, Oyelami OA, Oseni SB. A comparative study of the prevalence of zinc deficiency among children with acute diarrhoea in SouthWestern Nigeria. Afri Health Sci. 2020;20(1):406-12. https://dx.doi. org/10.4314/ahs.v20i1.47

46. Rouag M, Berrouague S, Djaber N, Khaldi T, Boumendjel M, Taibi F, et al. Pumpkin seed oil alleviates oxidative stress and liver damage induced by sodium nitrate in adult rats: biochemical and histological approach. Afri Health Sci. 2020;20(1):413-25. https://dx. doi.org/10.4314/ahs.v20i1.48

47. Kiringa SK, Quinlan J, Ocama P, Mutyaba I, Kagimu M. Prevalence, short term outcome and factors associated with survival in patients suffering from upper gastrointestinal bleeding in a resource limited-setting, the case of Mulago hospital in Kampala, Uganda. Afri Health Sci. 2020;20(1):426-36. https://dx.doi.org/10.4314/ ahs.v20i1.49

48. Dogan P, Ozkan H, Koksal N, Bagci O, Varal IG. Vitamin D deficiency and its effect on respiratory distress syndrome in premature infants: results from a prospective study in a tertiary care centre. Afri Health Sci. 2020;20(1):437-43.https://dx.doi.org/10.4314/ahs. v20i1.50

49. Hamouda S, Fredj SH, Hilioui S, Khalsi F, Ameur SB, Bouguila J, et al. Preliminary national report on cystic fibrosis epidemiology in Tunisia: the actual state of affairs. Afri Health Sci. 2020;20(1):444-52. https:// dx.doi.org/10.4314/ahs.v20i1.51

50. Mugivhisa LL, Dlamini N, Olowoyo JO. Adherence to safety practices and risks associated with health care waste management at an academic hospital, Pretoria, South Africa. Afri Health Sci. 2020;20(1):453-68. https://dx.doi.org/10.4314/ahs.v20i1.52

51. Pagning ALN, Tamokou J--D , Muhammad BT, Ngnokam D, Tapondjou LA, Ali MS, et al. Potential anti-proliferative effects of chemical constituents and hemisynthetic derivatives from Scadoxus pseudocaulus (Amarillydaceae). Afri Health Sci. 2020;20(1):469-75. https://dx.doi.org/10.4314/ahs.v20i1.53
52. Miranda-Rius J, Brunet-Llobet L, Lahor-Soler E, Mrina O, Mashala EI, Mahande MJ. Periodontal and dental conditions of a school population in a volcanic region of Tanzania with highly fluoridated community drinking water. Afri Health Sci. 2020;20(1):476-87. https://dx.doi.org/10.4314/ahs.v20i1.54

53. Yüksel S, Öztekin SD, Temiz Z, Uğraş GA, Şengül E, Teksöz S, et al. The effects of different degrees of head-of-bed elevation on the respiratory pattern and drainage following thyroidectomy: a randomized controlled trial. Afri Health Sci. 2020;20(1):488-97. https:// dx.doi.org/10.4314/ahs.v20i1.55

54. Winkler LA, Stypulkowski A, Noon S, Babwanga T, Lutahoire J. A multi-year analysis of kangaroo mother care outcomes in low birth weight babies at a Nyakahanga Hospital in rural Tanzania Afri Health Sci. 2020;20(1):498-508. https://dx.doi.org/10.4314/ahs. v20i1.56

55. Liu R, Yan Z, Zhang G, Ding Z, Li Y, Jiang Z. Comparison of digital subtraction angiography and contrast-enhanced ultrasound in assessment of carotid stenosis. Afri Health Sci. 2020;20(1):509-14. https://dx. doi.org/10.4314/ahs.v20i1.57

56. Kyei S, Dogbadze E, Tagoh S, Mwanza E. Unorthodox ophthalmic preparations on the Ghanaian market: a potential risk for ocular and enteric infections. Afri Health Sci. 2020;20(1):515-23. https://dx.doi. org/10.4314/ahs.v20i1.58

57. Viviers M, Jongh M, Dickonson L, Malan R, Pike T. Parent-reported feeding and swallowing difficulties of children with Autism Spectrum Disorders (aged 3 to 5 years) compared to typically developing peers: a South African study. Afri Health Sci. 2020;20(1):524-32. https://dx.doi.org/10.4314/ahs.v20i1.59

58. Woldeamanuel GG, Biru MD, Geta TG, Areru BA. Visual impairment and associated factors among primary school children in Gurage Zone, Southern Ethiopia. Afri Health Sci. 2020;20(1):533-42. https://dx.doi. org/10.4314/ahs.v20i1.60

59. Joob B, Wiwanitkit V. Letter to the editor: Vitamin D receptor gene BsmI polymorphism with type 2 diabetes mellitus. Afri Health Sci. 2020;20(1):543-4. https:/ / dx.doi.org/10.4314/ahs.v20i1.61

60. McKillup S. Letter to the editor: A discrepancy between methods and the interpretation of results: a comment on Umar et al's paper: Real time sonography as an anatomy teaching aid in undergraduate radiography institutions in Northern Nigeria. Afri Health Sci. 2020;20(1):545-8. https://dx.doi.org/10.4314/ahs. v20i1.62 